\title{
Anti -Inflammatory effects of Acacia catechu Seed Extract -an In vitro study
}

\author{
Hemashree J, Lakshmi T, Anitha Roy and Raghunandhakumar. S \\ ${ }^{1}$ Associate Professor,Department of Pharmacology, Saveetha Dental College, Saveetha Institute \\ of Medical and Technical Sciences, Saveetha University Chennai, Tamilnadu ,India.
}

\begin{abstract}
The Acacia catechu is also known by these names like Cutch tree, Terra Japonica as well as Black Catechu. It is also called Khair in hindin and Khadira in Sanskrit.This herb was previously known as Kat or Cacho. There are a lot of significant therapeutic purposes of Acacia catechu seed extract which includes Astringent ,Bactericidal ,Refrigerant ,Stimulant Masticator, Expectorant and anti- inflammatory actions. The aim of this study is to study the anti -inflammatory action of Acacia catechu seed extract. The estimation of anti inflammatory action was done using protein denaturation method. The inhibitory efficacy of the Acacia was better when compared to diclofenac sample which was used as a standard. Acacia catechu seed extract is a promising candidate for controlling the production of auto antigen by inhibiting the denaturation of protein and its effect by comparison with diclofenac.
\end{abstract}

\section{KEY WORDS: ACACIA CATECHU SEED EXTRACT, PROTEIN DENATURATION, ANTI INFLAMMATORY, DICLOFENAC.}

\section{INTRODUCTION}

The body's immediate response to damage tissues and cells by pathogens, certain stimuli such as chemicals or even by physical injury is referred to as inflammation. (Macfarlane et al., 2012)(Cruvinel et al., 2010). More recently, inflammation was described as "the succession of changes which occurs in a living tissue when it is injured provided that the injury is not of such a degree as to at once destroy its structure and vitality"or "the reaction to injury of the living microcirculation and related tissues (Spector and Willoughby, 1963; Cruvinel et al., 2010) .Inflammation is of two types : acute and chronic inflammation. Acute inflammation is a short term

\section{ARTICLE INFORMATION}

*Corresponding Author: lakshmi@saveetha.com

Received 4th Aug 2020 Accepted after revision 19th Sep 2020

Print ISSN: 0974-6455 Online ISSN: 2321-4007 CODEN: BBRCBA

Thomson Reuters ISI Web of Science Clarivate Analytics USA and Crossref Indexed Journal

\section{Clarivate
Analytics}

NAAS Journal Score 2020 (4.31) SJIF: 2020 (7.728)

A Society of Science and Nature Publication,

Bhopal India 2020. All rights reserved.

Online Contents Available at: http//www.bbrc.in/

Doi: http://dx.doi.org/10.21786/bbrc/13.8/174 response that usually results in healings. For example ; leukocytes infiltrate the damaged region, removing the stimulus and thus repairing the tissues. On the other hand, chronic inflammation is a prolonged, and unregulated response that involves acute inflammation ,tissue destruction and also attempts at tissue repair (Preisner et al., 2015) . Therefore, to treat any diseases with inflammatory reactions, natural products with anti inflammatory action can be chosen. Acacia catechu is such one product with impeccable properties.

There are about 1300 species of Acacia (family Mimosaceae), and its exudates, leaves, seeds, heartwood, and bark which are used in numerous ways(Thomas and Kearsley, 1993). Gum Acacia (gum arabic) has been used for its medicinal properties for approximately 2500 years. It is employed as a demulcent (soothing and protective agent) and emulsifier, and is used to increase viscosity of solutions and suspensions. It is also used in the food, soft drink, textile, tanning, cosmetic, and confection industries. The traditional preparation of betel quid (paan masala), which consists of Piper betle leaves, A. catechu paste, chopped Areca nut, lime, and various spices with or without tobacco is done by using Acacia Catechu 
heartwood extracts have also been used (Steven 1993). Betel chewing is used to produce euphoria, a sense of well-being, heightened sense of alertness, and psychostimulation .

The Acacia Catechu tree was a very important export product that was sent from India to China, Persia and Arabia in the early 16 th century particularly. This plant was used majorly for the purpose of dyeing and tanning. Japan takes the credit of introducing this plant to countries in Europe in the 17th Century. The tree of Acacia catechu is found all over the Indian country The main areas for its habitat in the country are the eastern slopes of the Western Ghats .This tree is deciduous and has short hooked spines that reach up to the height of 9 to 12 meters.

Recent studies reported that Acacia Catechu bark extract may aid to block the body's pain trigger mechanism. It possesses significant pharmacological, nutritive value. Acacia bark is hardened woody with a rusty appearance, brown color it contains tannins and Gallic acid. Acacia bark is commonly used in maintaining dental and oral hygiene. The fresh twigs are used for protection of gums and teeth. It is also considered useful as an external application for mouth ulcers and even reduces gingival inflammation (Singh, Mittal and Barthwal, 1976; Singh et al., 2010; Rahmatullah et al., 2013) Used in case of leprosy in rural areas.Certain studies have reported that the Acacia catechu induces apoptosis in human oral squamous carcinoma cells and other SCC-25 cells (Lakshmi et al., 2017) (Ezhilarasan et al., 2017)

To study the constituents of A. Catechu seed extract many studies were carried out. One such study done by Shen et al., 2006 shows that when aqueous extract of the heartwood and leaves of A. Catechu was subjected to high -performance liquid chromatography coupled with electrospray ionization mass spectroscopy reveals the primary constituents are catechins which by definition are gallic acid (polyhydroxylated benzoic acid) derivatives and polymers. Catechins , epicatechin, epicatechin-3- 0 -gallate, and epigallocatechin-3- 0 - gallate.p are the most predominant catechins.0ther secondary products present in the extracts includes flavonol glycosides, flavonal dimers, and caffeine. Li et al (Li et al., 2011) also found other constituents that have been identified in aqueous extracts of A. catechu include rhamnetin, 4-hydroxyphenol, 3,3',5, 5',7pentahydroxyflavone, fisetinidol, 5-hydroxy-2-[2-(4hydroxyphenyl)acetyl]-3-methoxybenzoic acid, and (2S,3S)-3,7,8,3',4'-pentahydroxyflavone. Thus, this study analyses the anti inflammatory action of Acacia Catechu seed extract in vitro specifically.

\section{MATERIAL AND METHODS}

Chemicals: Diclofenc sodium, dimethyl sulfoxide (DMSO) was purchased from Sigma Chemical Co. India. The other chemicals used in this study were purchased locally and were of analytical grade.
Plant collection and extract preparation: Acacia Catechu seed (ACS) was collected during the month of December 2015 from Hosur, Tamil Nadu, India, authenticated by Green Chem Lab, Bengaluru, Karnataka, India. Seeds were shade dried and were milled to fine powder. This seed powder was passed through 100 mesh sieves, and $2.5 \mathrm{~kg}$ of powdered ACS were extracted with $10 \mathrm{~L}$ of ethanolic, at $65^{\circ} \mathrm{C}$, for $1 \mathrm{~h}$. After $1 \mathrm{~h}$ of extraction, the extract was altered and collected. The marc, an insoluble residue was extracted repeatedly with $10 \mathrm{~L}$ of ethanolic, twice. The extract was evaporated in a Buchi rotary evaporator (Switzerland) at $65^{\circ} \mathrm{C}$, to obtain $150 \mathrm{~g}$ of powder extract. The $\mathrm{w} / \mathrm{w}$ yield of the prepared extract was $6 \%$.

Inhibition of Protein Denaturation method Concentration of test substance: 1000 to $200 \mu \mathrm{g} / \mathrm{ml}$ Standard : Diclofenac sodium

Chemicals Required : Bovine serum albumin, $1 \mathrm{~N} \mathrm{HCl}$, Phosphate buffer ( $\mathrm{pH}$ 6.3)

Instrument : Incubator, Spectrophotometer - 660nm

The following 4 solutions will be used

1. Test solution $(0.5 \mathrm{ml})$ consist of $0.45 \mathrm{ml}$ of bovine serum albumin (5\%w/v aqueous solution) and $0.05 \mathrm{ml}$ of test solution in various concentration and $\mathrm{pH}$ will be adjusted to 6.3 by using a small amount of $1 \mathrm{~N} \mathrm{Hcl}$.The samples were incubated at $370 \mathrm{C}$ for 20 minutes and heated at 570C for 3 minutes. After cooling, to the sample add $2.5 \mathrm{ml}$ of Phosphate buffer (pH 6.3).

2. Test control solution $(0.5 \mathrm{ml})$ consists of $0.45 \mathrm{ml}$ of Bovine serum albumin (5\% aqueous solution) and $0.05 \mathrm{ml}$ of distilled water and $\mathrm{pH}$ will be adjusted to 6.3 by using a small amount of $1 \mathrm{~N} \mathrm{Hcl}$ the samples were incubated at $370 \mathrm{C}$ for 20 minutes and heated at $570 \mathrm{C}$ for 3 minutes. After cooling, to the sample add $2.5 \mathrm{ml}$ of phosphate buffer ( $\mathrm{pH}$ 6.3)

3. Product control $(0.5 \mathrm{ml})$ consists of $0.45 \mathrm{ml}$ of distilled water and $0.05 \mathrm{ml}$ of test solution in various concentrations and $\mathrm{pH}$ will be adjusted to 6.3 by using a small amount of $1 \mathrm{~N} \mathrm{Hcl}$. The samples were incubated at 370C for 20 minutes and heated at 570C for 3 minutes. After cooling to the sample add $2.5 \mathrm{ml}$ to phosphate buffer (pH6.3)

4. Standard solution $(0.5 \mathrm{ml})$ consists of $0.45 \mathrm{ml}$ of bovine serum albumin (5\% w/v aqueous solution and $0.05 \mathrm{ml}$ of diclofenac sodium solution in various concentrations and $\mathrm{pH}$ will be adjusted to 6.3 by using a small amount of $1 \mathrm{~N} \mathrm{Hcl}$. The samples were incubated at 370C for 20 minutes and heated at 570C for 3 minutes. After cooling, to the sample add 2.5 $\mathrm{ml}$ of phosphate buffer (pH6.3)

The percentage inhibition of Protein denaturation will be calculated as follows:

$O D$ of test solution $-O D$ of product control

Percent Inhibition $=100-$-.-- X 100

OD of test control

The control represents $100 \%$ protein denaturation. The result will be compared with diclofenac sodium treated sample. 


\section{RESULTS AND DISCUSSION}

The results of the study is as follows

Table 1 . Percentage of inhibition for acacia catechu seed extract (test)

\begin{tabular}{|l|c|c|}
\hline S.No. & $\begin{array}{c}\text { Concentration } \\
(\mu \mathrm{g} / \mathrm{Ml})\end{array}$ & $\begin{array}{c}\% \text { Of } \\
\text { Inhibition }\end{array}$ \\
\hline 1 & 200 & 99.9 \\
\hline 2 & 400 & 99.6 \\
\hline 3 & 800 & 99.96 \\
\hline 4 & 1000 & 99.81 \\
\hline
\end{tabular}

Table 2. Percentage of inhibition for diclofenac sodium (standard)

\begin{tabular}{|l|c|r|}
\hline S.No. & $\begin{array}{c}\text { Concentration } \\
(\mu \mathrm{g} / \mathrm{Ml})\end{array}$ & $\begin{array}{r}\% \\
\text { Of Inhibition }\end{array}$ \\
\hline 1 & 200 & 99.88 \\
\hline 2 & 400 & 98.27 \\
\hline 3 & 800 & 99.52 \\
\hline 4 & 1000 & 99.45 \\
\hline
\end{tabular}

It is seen that the percentage of inhibitions varied for both the test and standard sample with varying concentrations. For instance, the \% inhibition for A. Catechu was 99.9 \% whereas it was 99.88 percent for standard sample at a concentration of $200 \mu \mathrm{g} / \mathrm{ml}$.Likewise, for $400 \mu \mathrm{g} / \mathrm{ml}$ concentration, the \% inhibition was 99.6 and 98.27 for A.catechu seed extract and standard sample respectively. The \% inhibition was 99.96 and 99.52 for the test and standard samples for a concentration of $800 \mu \mathrm{g} / \mathrm{ml}$. For a concentration of $1000 \mu \mathrm{g} / \mathrm{ml}$ the $\%$ of inhibition was 99.52 and 99.45 for the respective samples. It was seen that there were differences seen in the inhibitory activity for varying concentrations. This explains the potent antiinflammatory action of A. Catechu seed extract.

Moreover, Protein denaturation is one of the important known causes of certain anti inflammatory diseases. The mechanism of denaturation involves alteration of electrostatic hydrogen and disulphide bonding. Denaturation of protein in rheumatoid arthritis is probably due to auto antigen production. Hence Acacia Catechu seed extract is a promising candidate for controlling the production of auto antigen by inhibiting the denaturation of protein and its effect by comparison with diclofenac. This prospective study suggests a positive anti inflammatory action of Acacia Catechu seed extract against disease like rheumatoid arthritis. Several studies showed results similar to this study.For eg. A study done by Lakshmi et al shows that Acacia Catechu leaf extract has significant anti inflammatory properties against rheumatoid arthritis. The results were in accordance with our study.In another study the anti inflammatory efficacy of A. catechu bark extract was explored .It states that Acacia Catechu Bark exhibits significant anti inflammatory activity(Al-Gubory and Laher, 2018).

The ethanolic solvent form of Acacia Bark shows an inhibitory activity when tested at $200-1000 \mu \mathrm{g} / \mathrm{ml}$ by inhibiting denaturation of protein and its effect was compared with standard drug diclofenac sodium. Auto antigen production in rheumatoid arthritis is due to denaturation of protein. From the results of the present study it can be stated that ethanolic bark extract of Acacia Catechu is capable of controlling the production of auto antigen and inhibiting the protein denaturation in rheumatoid arthritis. Therefore it is clear that even the leaf and bark extract has significant potential just like the seed extract (Ghayathri and Lakshmi, 2015; Lakshmi, Ramasamy and Thirumalaikumaran, 2015). Not only Ayurvedic plants like Acacia several other herbal extracts are being used for their markable anti inflammatory properties (Lakshmi, Anitha and Geetha, 2011).

The results of different studies are discussed as below: Lycopodium clavatum also known as club moss has been reported to be used for anti inflammatory actions in wound healing effect. According to a study carried out by Orhan et al, (2007) extracts were prepared petroleum ether, chloroform, ethyl acetate and methanol as well as the alkaloidal fraction from the aerial parts of Lycopodium clavatum using acetic acid. This preparation seems to have induced an increase in capillary permeability assessment in mice, revealing that only the chloroform extract and the alkaloid fraction displayed marked anti-inflammatory effect when compared to Indomethacin. The evaluation of the anti inflammatory effect of X. caffra performed a study.The leaf extract on the LPS-stimulated expression of inflammatory enzymes and proinflammatory cytokines, the mRNA expressions of inflammatory markers IL-6, iNOS, and TNF- $\alpha$ were measured by qPCR.

Various studies have noted the presence of anti inflammatory and antioxidant properties in the silver nanoparticles synthesised from cumin oil (Jain, Anitha and Rajeshkumar, 2019; Keerthiga et al., 2019).In addition to it,they have anti diabetic properties as well (Phillips and Poon, 2012). Similarly silver nanoparticles were synthesised from ginger oil(Aafreen, Anitha and Preethi, 2019).The characterisation of these particles is done using visible spectrophotometer(Reddy et al., 2019). In addition to it, the green synthesis of the silver nanoparticles are useful against oral pathogens(Kandhan, Roy and Lakshmi, 2019).

The strongest response was seen for IL- 6, wherein treatment at $312.5 \mu \mathrm{g} / \mathrm{mL}$ induced a nearly 10 -fold decrease in expression versus background expression and nearly 100-fold decrease in expression versus LPS induced cells which were not treated by X. caffra leaf extract.This demonstrates clearly the anti inflammatory effects of X. caffra. Animal studies were done by Manjith et al to determine the anti inflammatory efficacy of Mirabilis Jalapa. In his study he said that anti- 
inflammatory activity was evaluated using carrageenan and formalin-induced paw edema models in Wistar albino rats. The anti-inflammatory activity was found to be dose dependent in the carrageenan-induced paw edema model.

The aqueous extract has shown significant $(\mathrm{P}<0.05)$ inhibition of paw oedema, $37.5 \%$ and $54.0 \%$ on 4 th hour at the doses of 200 and $400 \mathrm{mg} / \mathrm{kg}$, respectively. The results of this study demonstrated that aqueous extract of the leaves possess significant $(P<0.05)$ antiinflammatory potential (Zhen et al., 2015) . Besides antiinflammatory action ,Acacia Catechu is also known to be an Antihyperglycemic and Antinociceptive activity. Though, Diabetes mellitus is a disease currently affecting millions of people worldwide and with no known total cure in allopathic medicine. Moreover, the disease can quickly progress to cardiovascular disorders, diabetic retinopathy, and diabetic nephropathy. As such, a remedy obtained from khoyer, which even if it cannot cure the disease at least is effective in normalising the high blood sugar levels as seen in diabetic patients, can be a boon to human beings(Mizushima and Kobayashi, 1968).

\section{CONCLUSION}

This study explains the anti inflammatory properties of Acacia Catechu seed extract. The anti inflammatory activity is due to the presence of flavonoids, phenols, polyphenols, and steroids. Further studies are mandatory, to identify the active constituent(s), that is responsible for the anti inflammatory efficacy.

Author Contribution: All the authors have contributed mutually to prepare, conduct and approval of the Manuscript

\section{Conflict of Interest: Nil}

\section{REFERENCES}

Aafreen, M. M., Anitha, R. and Preethi, R. C. (2019) 'Anti-Inflammatory activity of silver nanoparticles prepared from ginger oil-an invitro approach', Indian Journal of. researchgate.net. Available at: https://www.researchgate.net/profile/Maysoon_AlHadraawy/publication/339390832_Study_Prevalence_ of_Breast_Cancer_and_the_Relation_it's_with_ Some_Risk_Factors_and_Blood_Group_in_Al-Najaf_ Governorate_Iraq/links/5e4efe94a6fdccd965b43e9f/ Study-Prevalence-of-Breast-Cancer-and-the-Relationits-with-Some-Risk-Factors-and-Blood-Group-in-AlNajaf-Governorate-Iraq.pdf\#page $=174$.

Al-Gubory, K. H. and Laher, I. (2018) Nutritional Antioxidant Therapies: Treatments and Perspectives. Springer.

Cruvinel, W. de M. et al. (2010) 'Immune system - part I. Fundamentals of innate immunity with emphasis on molecular and cellular mechanisms of inflammatory response', Revista brasileira de reumatologia, 50(4), pp.
434-461.

Ezhilarasan, D. et al. (2017) 'Acacia catechu ethanolic seed extract triggers apoptosis of SCC-25 cells', Pharmacognosy Magazine, p. 405. doi: 10.4103/ pm.pm_458_16.

Ghayathri, L. T. and Lakshmi, T. (2015) 'Antiinflammatory activity of acacia catechu bark extract-in vitro study', Journal of chemical and pharmaceutical research, 7(7), pp. 1184-1187.

Jain, A., Anitha, R. and Rajeshkumar, S. (2019) 'Anti inflammatory activity of Silver nanoparticles synthesised using Cumin oil', Research Journal of Pharmacy and Technology. A \& V Publications, 12(6), pp. 2790-2793.

Kandhan, T. S., Roy, A. and Lakshmi, T. (2019) 'Green synthesis of Rosemary oleoresin mediated silver nanoparticles and its effect on Oral pathogens', Research Journal of. indianjournals.com. Available at: http:// www.indianjournals.com/ijor.aspx?target=ijor:rjpt\&tv olume $=12$ Etissue $=11$ tarticle $=045$.

Keerthiga, N. et al. (2019) 'Antioxidant activity of cumin oil mediated silver nanoparticles', Pharmacognosy Journal, 11(4). Available at: http://www.phcogj.com/ article/930.

Lakshmi, T. et al. (2017) 'Acacia catechu ethanolic bark extract induces apoptosis in human oral squamous carcinoma cells', Journal of advanced pharmaceutical technology \&t research, 8(4), pp. 143-149.

Lakshmi, T., Anitha, R. and Geetha, R. V. (2011) 'Acacia catechu willd-A gift from Ayurveda to mankind-A review', T Ph Res, 5(2), pp. 273-293.

Lakshmi, T., Ramasamy, R. and Thirumalaikumaran, R. (2015) 'Preliminary Phytochemical analysis and In vitro Antioxidant, FTIR Spectroscopy, Anti-diabetic activity of Acacia catechu ethanolic seed extract', Pharmacognosy Journal, pp. 356-362. doi: 10.5530/ pj.2015.6.7.

Li, X.-C. et al. (2011) 'Phenolic compounds from the aqueous extract of Acacia catechu', Journal of Asian natural products research, 13(9), pp. 826-830.

Macfarlane, G. J. et al. (2012) 'A systematic review of evidence for the effectiveness of practitionerbased complementary and alternative therapies in the management of rheumatic diseases: rheumatoid arthritis', Rheumatology, pp. 1707-1713. doi: 10.1093/ rheumatology/kes133.

Mizushima, Y. and Kobayashi, M. (1968) 'Interaction of anti-inflammatory drugs with serum proteins, especially with some biologically active proteins', Journal of Pharmacy and Pharmacology, pp. 169-173. doi: 10.1111/j.2042-7158.1968.tb09718.x.

Phillips, C. R. and Poon, Y. C. (2012) Immobilization of Cells. Springer Science \& Business Media. 
Preisner, A. et al. (2015) 'Non-steroidal antiinflammatory drug indometacin enhances endogenous remyelination', Acta Neuropathologica, pp. 247-261. doi: 10.1007/s00401-015-1426-z.

Rahmatullah, M. et al. (2013) 'Antihyperglycemic and antinociceptive activity evaluation of "Khoyer" prepared from boiling the wood of Acacia catechu in water', African Journal of Traditional, Complementary and Alternative Medicines. doi: 10.4314/ajtcam.v10i4.1.

Reddy, J. M. et al. (2019) 'Characterisation of Cumin oil mediated silver nanoparticles using UV-visible spectrophotometer and TEM', Research Journal of Pharmacy and Technology, p. 4931. doi: 10.5958/0974360x.2019.00855.2.

Singh, K. N., Mittal, R. K. and Barthwal, K. C. (1976) 'Hypoglycaemic activity of Acacia catechu, Acacia suma, and Albizzia odoratissima seed diets in normal albino rats', The Indian journal of medical research, 64(5), pp. 754-757.

Singh, M. et al. (2010) 'Anti-inflammatory activity of aqueous extract of Mirabilis jalapa Linn. leaves', Pharmacognosy research, 2(6), pp. 364-367.

Spector, W. G. and Willoughby, D. A. (1963) 'THE INFLAMMATORY RESPONSE', Bacteriological Reviews, pp. 117-154. doi: 10.1128/mmbr.27.2.117-154.1963.

Thomas, S. and Kearsley, J. (1993) 'Betel quid and oral cancer: A review', European Journal of Cancer Part B: Oral Oncology, pp. 251-255. doi: 10.1016/09641955(93)90044-f.

Zhen, J. et al. (2015) 'Phytochemical Analysis and AntiInflammatory Activity of the Extracts of the African Medicinal Plant Ximenia caffra', Journal of analytical methods in chemistry, 2015, p. 948262. 